\title{
Correction to: A downstream box fusion allows stable accumulation of a bacterial cellulase in Chlamydomonas reinhardtii chloroplasts
}

\author{
Lubna V. Richter ${ }^{1}$, Huijun Yang ${ }^{1,2}$, Mohammad Yazdani ${ }^{1}$, Maureen R. Hanson ${ }^{2}$ and Beth A. Ahner ${ }^{1 *}(\mathbb{D}$
}

\section{Correction to: Biotechnol Biofuels (2018) 11:133} https://doi.org/10.1186/s13068-018-1127-7

In the original version of the article [1], a calculation error resulted in a 3-order of magnitude mistake for the $\mathrm{y}$-axis of the data reported in Fig. $5 \mathrm{c}$ and d. The new figures are labeled as "pg/cell" (Fig. 5c, formerly "ng/cell") and "fg/cell" (Fig. 5d, formerly "ng/cell $\times 10^{-3 ")}$.

The only textual reference to these units is on page 6 of the MS. The correct sentence should be:
“The TetC-Cel6A content of cells (pg/cell) mirrored extractable protein to a large extent, increasing gradually in $\mathrm{N}$-replete cells and increasing more rapidly in $\mathrm{N}$-deplete cells, with the highest cellular levels recorded after $24 \mathrm{~h}$ of $\mathrm{N}$-starvation (Fig. 5d)."

The correct figure is published in this correction article. 


\section{a}

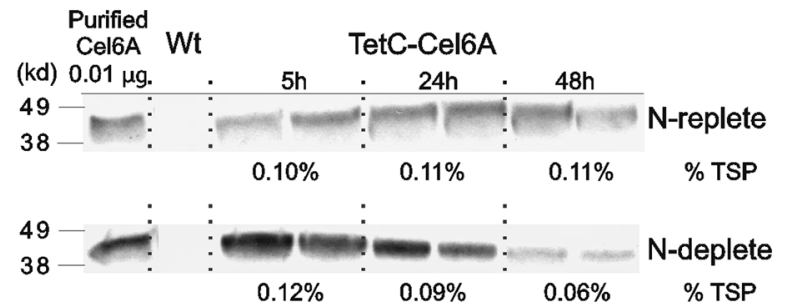

b N-replete

N-deplete

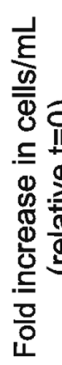
3 $\left.\begin{array}{l}3 \\ 2 \\ 1 \\ 0\end{array}\right]$<smiles>C[AlH]C</smiles>

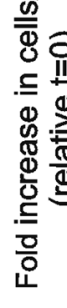
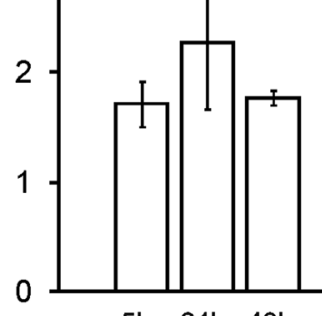

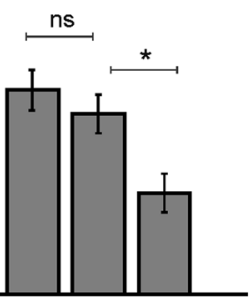

$5 \mathrm{~h} \quad 24 \mathrm{~h} \quad 48 \mathrm{~h}$

$5 \mathrm{~h} 24 \mathrm{~h} 48 \mathrm{~h}$

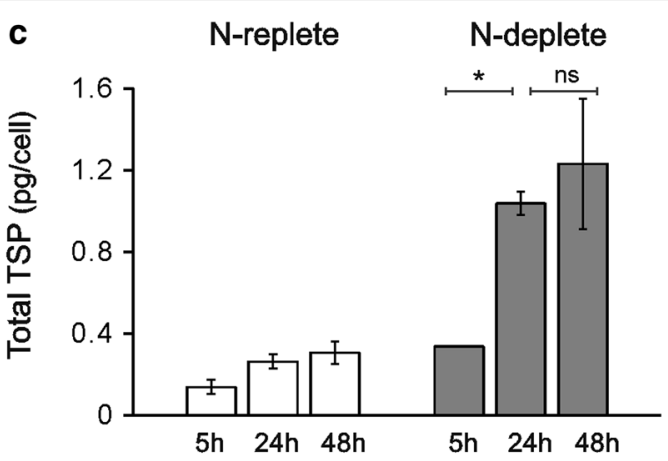

d

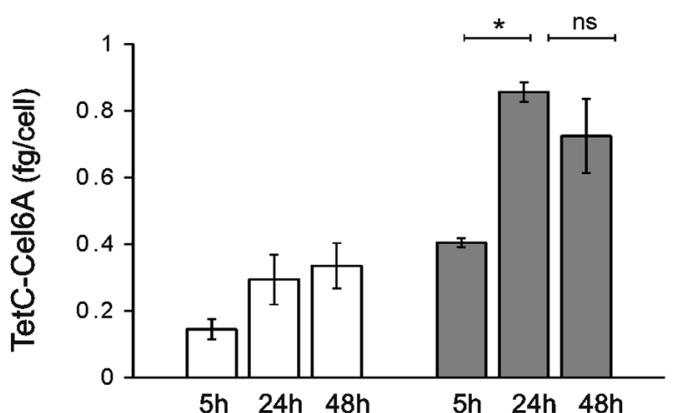

Fig. 5 Effect of nitrogen starvation on the accumulation of TetC-Cel6A. a Immunoblots showing the TetC-Cel6A protein accumulation after 5 , 24 , and $48 \mathrm{~h}$ of resuspension in $\mathrm{N}$-replete (top blot) or $\mathrm{N}$-deplete (bottom blot) minimal media. Exposure time was 2 min for both blots. All lanes contained $10 \mu \mathrm{g}$ total soluble protein. Control lane contained $0.01 \mu \mathrm{g}$ purified Cel6A protein. The TetC-Cel6A protein accumulation was quantified in two biological replicates by comparing the relative blot density of bands to those of a purified Cel6A control. b-d Several parameters monitored in the TetC-Cel6A expressing cells grown under $\mathrm{N}$-replete or $\mathrm{N}$-deplete media for 5, 24, and $48 \mathrm{~h}$. Data are the average of two biological replicates per treatment and time point. Error bars are the standard error of the mean. Statistical analysis were performed by Student's t test, ${ }^{*} \mathrm{p}<0.05$ and ns $=$ not significant

\section{Author details}

${ }^{1}$ Department of Biological and Environmental Engineering, Cornell University, 111 Wing Drive, Ithaca, NY, USA. ${ }^{2}$ Department of Molecular Biology and Genetics, Cornell University, Biotechnology Building, Ithaca, NY, USA.

Received: 16 November 2016 Accepted: 23 April 2018

Published online: 10 December 2019

\section{Reference}

1. Richter LV, Yang H, Yazdani M, Hanson MR, Ahner BA. A downstream box fusion allows stable accumulation of a bacterial cellulase in Chlamydomonas reinhardtii chloroplasts. Biotechnol Biofuels. 2018;11:133. https://doi.org/10.1186/s13068-018-1127-7.

\section{Publisher's Note}

Springer Nature remains neutral with regard to jurisdictional claims in published maps and institutional affiliations. 